Christian M. Billing

\title{
Review of The Puppet and the Modern
}

Marie JIRÁSKOVÁ and Pavel JIRÁSEK. The Puppet and the Modern: [The] Visual Style of Czech Family Puppet Theaters, Theater Clubs and Art Scenes in the Early $20^{\text {th }}$ Century as a Unique Reflection of Avant-Garde and Modernist Currents by Czech Artists. Transl. by Magdalena and Lawrence Wells. Prague: Arbor vitae, 2014. 470pp. ISBN 978-8-0746-7056-5.*

Every once in a while, a volume comes along that is not only a meticulously researched and well-written addition to scholarship in the area, but is also, very evidently, a labour of love. Such a volume is Marie Jiráskovás and Pavel Jirásek's The Puppet and the Modern.

It is notoriously difficult for academic publishing about theatre to incorporate and communicate a sense of the ephemerality and materiality of its subject (there are many reasons for this, not least of which, I would propose, is the inability of perhaps a majority of academic authors to think in reified as well as in abstract theoretical terms about their subject), but this volume achieves just that nirvana, that holy grail of theatre-historical criticism: it sets the physical reality of a visual and (arte)factual account of its subject (the material development of Czech puppetry through the late nineteenth to the mid-twentieth centuries) against a historicised and theoretically astute textual enquiry that considers many of the most important names, dates, places and producers of Czech puppet scenography, puppet dramaturgy and, most importantly: the design and functionality of the puppets themselves from 1900-1950.

Why should this book be so extraordinary? and why should the Jiráseks have done it so well? The answer is simple: they love puppets; they live puppets; and they are deeply and personally embedded within a quotidian existence that involves looking at, handling, and thinking about these (mostly wooden) delights - not only as objects of material splendour, but also as historical traces of past practices, practitioners and performers. As such authorindividuals, Marie Jirásková and Pavel Jirásek bring with them the embodied travail that only the first-rate amongst authors can achieve: the phenomenological être au monde of those who actually practice what they preach. In an age of philistinism, careerism, output-driven research agendas, of the devising of projects that can (we all hope!) attract the latest grant, of publications that merely cater to the latest academic fad... this is indeed a rare thing in our discipline - and in the effective communication of their personal connectedness with their subject, these authors have paid great attention to detail in their selection of both visual examples and tex-

\footnotetext{
* Also published in Czech as: Loutka a moderna: Vizualita českého loutkového rodinného divadla, spolkového divadla a uměleckých scén v první polovině dvacátého století jako osobitý odraz avantgardních a modernistických snah českých výtvarných umělců. Praha and Brno: Arbor vitae, 2011. 456pp. ISBN 978-8-0871-6485-3.
} 
tual evidence bases. Why shouldn't they? They have it all at their fingertips. These puppets are their babies. They are the parents of this volume.

Such virtue and command of the subject can be seen in a variety of aspects: from important details such as their arrangements of objects for photography (the people who posed these puppets know how they work!), through the visual aesthetics of the photographs themselves (observe the way that light falls upon these performance objects in theatrical and dramatic ways), through to the ways in which puppets, scenography and other documentary evidence are themselves physically presented in the volume, both alongside and within analytical text. In this book, illustrations are not just afterthoughts - the necessary, but expensive (in publication terms) visualisation of a verbal argument - they are rather a central part of the book's overarching arguments; and a means of shaping the ways in which the cognitive engagement of any reader can be aided and modelled visually just as much as linguistically. In short - and from me this is high praise indeed - this book is truly theatrical - in its ambition, in its layout, in the articulation of its thesis, and in the shaping of its verbal execution.

Congratulations! I love your book! More prosaically, perhaps, here is some detail on the contents of the volume and its detailed successes and failures:

Despite a title that leads one (incorrectly) to preconceive of this work as being uniquely about the period from 1900 to around 1950 (and thus giving the reader an idea that the work more directly embraces and is limited to the period of
pan-European High Modernism that lurks behind this volume's title), the book's historical remit is actually quite wide. Its contextual references and artistic figures span, in fact, from the sixteenth century to the mid-1960s. Such an ability to draw on the historical roots of Czech Modernist puppetry (which is undoubtedly the book's main subject) is evidence of the authors' significant knowledge of their wider specialty, and it also provides concrete proof of their maxim: 'Modern Czech Puppet Stage Design Begins in Retrospect.' In other words, it is a great advantage that this book sensibly acknowledges the general truth that: 'to know any historical period properly, one must not only know its immediate historical context, but also one should understand that moment's antecedents and its successors' (Billing).

The most detailed section of the book to deal with such 'roots' is the section on 'Puppet Stage Design in the Era of the Puppetry Renaissance' (pp. 36-173), which slowly moves readers through the reinvention and reinvigoration of Czech puppet theatre that took and re-modelled the historical and folk forms that had been preserved in Czech culture and performance traditions throughout the eighteenth and nineteenth centuries. However, the vast bulk of the volume, which deals with the period of grand experimentation that took place from $c a .1900$ to $c a .1950$, frequently also uses an elliptical historiographical methodology of chronological and cultural contextualisation that is both sophisticated and welcome. Because the ways of re-interpreting, shaping and moulding Czech puppets as a truly 'Modern' means 
of artistic expression do not adhere to simple timeline, and because Czech puppet theatre was neither an activity undertaken in a single artistic realm, nor by a single group or school of puppetry, the book does not present a unifying historical narrative (it is one of its great virtues that it is not that naive); rather, it offers a series of intersecting and overlapping micro-histories that look in detail at particularly important practitioners, competing milieux and divergent technological approaches and developments. Thus on a meta-level, the juxtapositional nature of the writing and structure of the volume matches the visual imperative of comparing and contrasting the book's hundreds of visual images. This is more than brilliantly sophisticated writing; it is brilliantly sophisticated book design - and thus a re-evaluation of the primacy of the reader (and their own comparative, temporal and juxtapositional processes) in achieving the act of reading/ interpreting a polysemous visual text.

To set out the contents of the volume: it is broadly divided into seven sections, but these can easily be 'chunked up' (by me at least) into what I see as the three 'acts' of the book as a whole. In the first 'act' fall sections 1-3 (pp. 34-173): in these, the authors deal respectively with (1) puppet stage design in the era of the Puppetry Renaissance (with sections on Mikolás Aleš, Rudolf Livora, Zdeněk Weidner and other less famous, but perhaps equally important, providers of the scenography for puppet shows). (2) The ways in which the expressive carving of the Czech historical tradition were deployed in more modern contexts (with specific reference to the
Baroque style of the Sucharda family, the styles inherent in the medievally rooted traditions of the town of Kutna Hora, the typographies of traditional marionette styles and the magical and mannerist work of Alois Šroif). (3) The transitional influence of puppet and stage designs of the Art Nouveau and Art Deco periods (with a focus on major artists such as Josef Šejnost, Josef Váchal, Ladislav Šaloun, as well as trends towards stylisation, exaggeration and painterly-art influenced modes of theatrical presentation). Here, one of the great achievements of this section of the volume is the fact that it sets out puppet Realism (such as that of Vít Skála) as just one more amongst the many Avant-garde art forms of the period - and juxtaposes both puppet and wider theatre Realism and Naturalism against equally-radical-at-the-time exercises such as Impressionism and... wait for it... Family [Puppet] Theatre! In such breadth of coverage (and in seeing each individual attempt at performative reinvention as an Avant-garde in itself) lies another of the volume's great virtues.

In the second act (as I am here terming them), sections 4-6 (pp. 174-384), we have a more intently scenographic and technical focus, with discussion of numerous individual puppets and stage designs for theatre clubs and family puppet theatres. Here we see analysis of family theatres, school and theatre clubs, analysis of serially produced scenography and puppet design, the development of stylized geometrical settings, as well as an account of the exploitation of the fairy-tale within Art Nouveau. Technological developments come next, largely prompted by the move 
from hand carving to the machine lathe and what I would call 'machine-turned', but which the authors call 'lathed' puppets. In this section, significant attention is paid to the impact of the relationship between manufacturing technology and its effects on Avant-garde practice; put simply, this involves some rather clever accounts of the development of serially produced puppets and the development of a working scenography in which they could be placed - together with an assertion that this led to the concomitant development of a stripped-down, more Modern (read less artisanal, less folk-inspired) aesthetic in more serious professional and also professional-level amateur practice. For me, this is one of the most impressive sections of the book, both in terms of the narrative analysis, but also in terms of the way in which the juxtaposition of visual evidence is used to influence the reader's engagement with and appreciation of the academic argument being put forward. Seeing the more stripped-down aesthetic of machine-turned puppets (and their historical and industrial connections to mass-produced toys) suddenly made sense for me of the relationship between the clean lines of technological production and much Modernist art of this period. When the toys one's children play with look a certain way, the way one thinks about art/theatre/puppets will be significantly altered. With the juxtapositional visual evidence so clearly presented it's easy to see the argument as persuasive.

Section 6 of the volume (pp. 298-384) looks at what has by many been seen as a key moment of the development of modern Czech puppet theatre: the 1930s and early 1940s. Here, the authors deal with the 'Czech puppet cult' that existed 'on the cusp of the 1930s', the work of the company Theatre Radost, the development of caricature by Ondřej Sekora, and the major developments (particularly in aesthetic mastery) as it was displayed by Josef Skupa and Antonín Procházka. Also treated are puppets and techniques developed and deployed by Nosek, Jan Vavř́ík Rýz, Jan Malík and several other important, but lesser known, figures.

In the third 'act' (my divisions), section 7 (pp. 384-434) it is almost as if a tragic curtain is drawn. The section is entitled 'Czech Puppet Stage Design during the Protectorate of Bohemia and Moravia and the Second Half of the 1940s. The conclusion provided by this section is an interesting indication of the non-Soviet-period start to the latterly on-going social and political oppression of the Czech puppet tradition. We have become familiar with the arguments about inventiveness, metaphor, irony and the centrality of material, visual and scenographic plasticity in the usurpation, subversion and flouting of Social Realism and the oppressive regime of so-called 'Normalisation' in Czech puppet (and other) theatre. Here, once again, the Jiráseks are ahead of the game. In their account of the 1940s oppression of Czech puppetry as a way to the development of a new aesthetic for professional puppet theatre (and later in their analysis of Jaroslav Šváb, Rudolf Ř́ha, Rudolf Kokoška and others), the authors demonstrate the ways in which practitioners always use the tools and means of their profession to work within, whilst at the same time cri- 
tiquing and subverting, the 'rules' of any dominant oligarchy. As such, and almost without saying it (for such is the beauty of their volume as a whole), the book concludes with what might be called an 'analytical roadmap' for the delicate path of the years with which this volume does not deal: 1950-1989. Significantly, perhaps our own contemporary Czech puppet theatre has got lost as a result of this rejection of plasticity and the decline of a milieu that values and trades in inventiveness in relation to the manipulative control of the real, actualised, material forms with which this volume deals. Without the 'shock of the new', or in opposition to forms of social and political oppression that demand inventiveness, we may well have become complacent.
In their account of the early necessity to think creatively that existed in a culture in which anything did NOT go and in which everything had NOT been done bbefore, the Jiráseks outline the difficulties, but also the grand artistic merits and challenges of the period in question. In both their analyses and in their artefactual visual presentation, Marie Jiráskovás and Pavel Jirásek's The Puppet and the Modern presents the topic and its products most beautifully.

This is a volume to be prized amongst the bibliography on Czech puppet theatre. It is a volume to be bought, to be looked at, to be read and to be treasured.

DOI 10.5817/TY2015-2-15 